Grzybowska A., Konkurencyjność przedsiębiorstw w obliczu procesów globalizacji, „Ekonomia i Prawo", Polszakiewicz B., Boehlke J. (red.), Tom XII, nr 3/2013, ss. 507-516. DOI: http:// dx.doi.org/10.12775/EiP.2013.037

\author{
AgNIESZKA GRZYBOWSKA*
}

\title{
KONKURENCYJNOŚĆ PRZEDSIĘBIORSTW W OBLICZU PROCESÓW GLOBALIZACJI
}

\section{STRESZCZENIE}

W warunkach globalizacji nowe sytuacje, nowe możliwości pojawiają się nagle, powodując wyzwania, którym sprostanie może być jedyną szansą zaistnienia lub utrzymania się na rynku. Przedsiębiorstwa muszą błyskawicznie wręcz reagować na rynek, bo to co jest efektywne dziś, jutro już takim być nie musi. Zmiany w gospodarce zachodziły zawsze, ale obecne ich tempo wydaje się nieporównywalne. Współczesne przedsiębiorstwo to przedsiębiorstwo ciągle wybiegające w przyszłość, poszukujące i rozwiązujące problemy, które jeszcze się nie pojawiły. To przedsiębiorstwo myślące kategoriami jutra.

Słowa kluczowe: globalizacja, przedsiębiorstwo

Klasyfikacja JEL: D01, F61

\section{COMPETITIVENESS OF ENTERPRISES IN THE LIGHT OF GLOBALIZATION PROCESS}

\section{SUMMARY}

Globalization creates new situation, new possibilities, which appear suddenly causing challenges, which enterprises should meet to start or continue their activity.

* Agnieszka Grzybowska, Uniwersytetu w Białymstoku, Wydział Ekonomii i Zarządzania, Katedra Ekonomii Politycznej, e-mail: a.grzybowska@uwb.edu.pl. 
Enterprises have to respond quickly on changing market condition as what is effective today, tomorrow it is not necessarily so. Changes in the economy always occurred, but the current pace of progress seems to be incomparable. A contemporary enterprise is the company continuously looking ahead, searching and solving problems that have not yet emerged. Thinking of better tomorrow is typical for such enterprise.

Keywords: globalization, business

JEL Classification: D01, F61

\section{WSTĘP}

Efektywne działanie przedsiębiorstw, funkcjonujących w dynamicznie zmieniających się warunkach, jest bardzo mocno uzależnione od możliwości reagowania na sygnały płynące $\mathrm{z}$ rynku. Reakcja wiąże się najczęściej z koniecznością wprowadzania zmian w zakresie rozwiązań technicznych, technologicznych i organizacyjnych. Jednocześnie bierność jednostki lub zbyt wolne reagowanie może przyczynić się do jej upadłości. Przedsiębiorstwo, aby przetrwać i efektywnie funkcjonować w konkurencyjnym otoczeniu, powinno w swojej strategii rozwoju uwzględniać proces globalizacji. Sprostanie globalnej konkurencji niejednokrotnie wymaga zmiany sposobu myślenia, a często również zmian w samym sposobie prowadzenia przedsiębiorstwa. Celem artykułu jest próba odpowiedzi na pytanie, jakie powinno być przedsiębiorstwo, aby mogło sprostać globalizacji, skutecznie radząc sobie $\mathrm{z}$ nowymi warunkami.

\section{GLOBALIZACJA PRZEDSIĘBIORSTW I KONKURENCJI}

Różne ujęcia globalizacji, jak i poziomy jej analizy wskazują, że jest to zjawisko wieloaspektowe i może być w różny sposób analizowane. W niniejszym opracowaniu rozważania zostaną skupione na wymiarze ekonomicznym globalizacji. Wydaje się, iż najpełniejsza definicja w tym wymiarze traktuje globalizację jako długofalowe integrowanie się działalności na poziomie gospodarek, sektorów oraz przedsiębiorstw ponad granicami państw dzięki rozszerzeniu, pogłębianiu oraz intensyfikowaniu różnego rodzaju powiązań, co prowadzi do tworzenia współzależnego systemu ekonomicznego w skali światowej ${ }^{1}$.

${ }_{1}$ Por. A. Gorczyńska, Globalizacja jako czynniki wspótczesnego wymiaru funkcjonowania przedsiębiorstw, [w]: W. Caputa, D. Szwajca (red.), Potencjat konkurencyjny przedsiębiorstwa w warunkach globalizacji, CedeWu.pl, Warszawa 2010, s. 8. 
Proces globalizacji przedsiębiorstwa jest konsekwencją zmian zachodzących we współczesnej gospodarce. Dotyczy to szczególnie zmian wymuszonych postępem technicznym, ale również zmian jakości życia społecznego i politycznego mających wpływ na warunki współpracy na arenie międzynarodowej. Globalizacja przedsiębiorstw powoduje ich umiędzynarodowienie, co oznacza zaangażowanie przedsiębiorstw w międzynarodową działalność produkcyjną i handlową oraz możliwość świadczenia pełnego pakietu usług².

$\mathrm{Z}$ punktu widzenia zarządzania przedsiębiorstwem istotą globalizacji jest zmiana perspektywy postrzegania zdarzeń, zachowań, działań, uznawanych wartości - $\mathrm{z}$ narodowej na ogólnoświatową. Przedsiębiorstwo jest postrzegane jako główny podmiot procesu globalizacji, na co wskazują następujące przyczyny³: - wysoka elastyczność przedsiębiorstw, polegająca na umiejętności dostosowania się do procesu globalizacji; wdrażanie strategii globalizacji w przedsiębiorstwach jest znacznie łatwiejsze niż urzeczywistnianie jej przez rząd, związki zawodowe czy jednostki naukowe;

- przywiązywanie przez społeczeństwo wagi do konieczności wzrostu produkcji, co przyczyniło się do dominacji przedsiębiorstw realizujących oczekiwania klientów;

- nieprzydatność analiz światowych statystyk przepływów handlowych między państwami ze względu na to, iż część z nich odbywa się między przedsiębiorstwami; traktowanie światowej gospodarki jako systemu wolnej wymiany i przepływów nie odpowiada rzeczywistym procesom;

- utrata kontroli przez rządy nad większością czynników i procesów determinujących gospodarczy rozwój kraju w przeciwieństwie do przedsiębiorstw ponadnarodowych, które są w stanie kontrolować i przebieg i skalę procesów.

Przedsiębiorstwo w procesie globalizacji ma do odegrania niezmiernie trudną rolę, która wynika z kilku powodów. Po pierwsze, nowa rola przedsiębiorstwa, jest nie do określenia. Po drugie, istnieje problem tożsamości narodowej przedsiębiorstw. Wraz z rozwojem globalizacji słabnie znaczenie, z jakiego kraju pochodzą dane produkty czy usługi (dla oznaczenia producenta podaje się na przykład formułę: wyprodukowano w UE). Po trzecie przedsiębiorstwa coraz częściej stają się przedmiotem obrotu handlowego: są kupowane i sprzedawane. Dzisiaj są własnością jednych inwestorów, jutro drugich. Po czwarte, globalizacja narzuciła przedsiębiorstwom niesłychanie trudne warunki do przetrwania ${ }^{4}$.

${ }^{2}$ H.G. Adamkiewicz-Drwiłło, Konkurencyjność przedsiębiorstw w świetle uwarunkowań wspótczesnej gospodarki, Wydawnictwo Dom Organizatora, Toruń 2010, s. 388-389.

3 Ibidem, s. 390.

${ }^{4}$ http://globalizacja.genialne.info/globalizacja_przedsiebiorstw.html (18.02.2013). 
Występowanie i natężenie globalnej konkurencji powiązane jest ze stopniem globalizacji danego sektora, która zależy od jego specyfiki i czynników sprzyjających, grupowanych najczęściej w czterech głównych kategoriach ${ }^{5}$ :

- czynników rynkowych, takich jak ujednolicenie potrzeb konsumentów sprzyjające standaryzacji produktu, globalizowanie kanałów dystrybucji i klientów oraz strategia marketingowa zawierająca elementy globalne;

- czynników kosztowych, do których zalicza się korzyści skali i zasięgu, korzyści z nauki i doświadczenia, centralizację zaopatrzenia, zróżnicowanie w kosztach i jakości czynników produkcji;

- czynników rządowych wyrażających się w charakterze prowadzonej polityki sprzyjającej rozwojowi handlu, ujednoliceniu standardów technicznych oraz przyjmowaniu wspólnych regulacji określających zasady i sposoby działań o charakterze marketingowym;

- czynników konkurencyjnych, które nie są stałe i niezależne od działań podmiotów, ale pozostają w sferze wyboru konkurentów i wiążą się ze świadomym wyborem globalnej strategii konkurencji.

W tradycyjnej konkurencji przedsiębiorstwa działając na zasadzie konfrontacji z pozostałymi podmiotami obecnymi na rynku dążyły do osiagania samowystarczalności. Wraz z procesem globalizacji widoczna jest zmiana podejścia do budowania struktur biznesowych oraz charakteru relacji pomiędzy przedsiębiorstwami w kierunku podejmowania różnych form współpracy, takich jak na przykład kooperacja. Podmioty pełnią względem siebie role partnerów, a nie konkurencji.

Globalizacja przedsiębiorstw, wspólistniejąc z procesem globalizacji konkurencji, spowodowała wzrost zainteresowania kreowaniem własnej konkurencyjności. Związana jest z tym konieczność określenia właściwej strategii rozwoju przedsiębiorstwa, w której konkurencyjność byłaby jednym z istotniejszych elementów.

\section{UWARUNKOWANIA KONKURENCYJNOŚCI PRZEDSIĘBIORSTW}

Konkurowanie pomiędzy przedsiębiorstwami jest immanentną cechą gospodarki rynkowej. W zależności od branży bądź sektora może odbywać się na wielu płaszczyznach i przejawiać się w różnych metodach oraz formach

5 S. Talar, Zmiany natężenia, charakteru i znaczenia konkurencji we wspótczesnej gospodarce swiatowej, [w]: T. Sporka, S. Talar (red.), Internacjonalizacja i konkurencyjność wspótczesnych podmiotów gospodarczych, Wydawnictwo Uniwersytetu Ekonomicznego w Katowicach, Katowice, 2011, s. 19-20. 
działania, a także mieć zróżnicowane natężenie. $Z$ punktu widzenia praktyki istotne jest rozpoznanie i zrozumienie, jakie uwarunkowania i czynniki mają wpływ na konkurencyjność przedsiębiorstwa ${ }^{6}$.

Konkurencyjność stwarza w gospodarce rynkowej możliwości rozwoju dla różnych przedsiębiorstw ${ }^{7}$. Konkurencyjność ma charakter względny, bowiem należy dokonać wyboru właściwych obiektów odniesienia oraz przyjęcia odpowiednich kryteriów i mierników oceny poziomu konkurencyjności ${ }^{8}$. Konkurencyjność danej firmy jest analizowana na tle innych podmiotów funkcjonujących w tym samym sektorze i jest postrzegana jako wynik podejmowanych przez przedsiębiorstwo działań.

Konkurencyjność przedsiębiorstw można rozpatrywać jako system tworzony przez'

- potencjał konkurencyjności, rozumiany jako ogół materialnych i niematerialnych zasobów przedsiębiorstwa, kluczowych kompetencji i zdolności, umożliwiających zdobycie trwałej przewagi konkurencyjnej;

- przewagę konkurencyjną, rozumianą jako efekt skutecznego wykorzystywania składników potencjału konkurencyjności umożliwiających przedsiębiorstwu generowanie atrakcyjnej oferty rynkowej i skutecznych instrumentów konkurowania;

- instrumenty konkurowania, określane jako świadomie i celowo wykorzystywane narzędzia i metody budowania kapitału klientów oraz kreowania wartości firmy;

- pozycję konkurencyjną, rozumianą jako osiągnięty przez przedsiębiorstwo wynik konkurowania w danym sektorze, rozpatrywany na tle wyników osiąganych przez konkurentów.

Przedstawione ujęcie odzwierciedla szereg istotnych czynników i uwarunkowań rzutujących na konkurencyjność przedsiębiorstwa w praktyce zarządzania.

Kluczowe determinanty konkurencyjności współczesnych przedsiębiorstw mają charakter interaktywny, są bowiem splotem wzajemnie powiązanych ze sobą czynników, które tworzą wielowymiarową przestrzeń. Nie należy ich postrzegać jako pojedynczych wyizolowanych zmiennych, lecz jako zbiór wza-

${ }^{6}$ W. Walczak, Analiza czynników wptywających na konkurencyjność przedsiębiorstw, „E-mentor", nr 5 (37)/2010, http://www.e-mentor.edu.pl/artykul/index/numer/37/id/784 (18.02.2013).

${ }^{7}$ M. A. Leśniewski, Konkurencyjnośc przedsiębiorstw. Wybrane problemy, Dom Organizatora, Toruń 2011, s. 227.

${ }^{8}$ M. Gorynia (red.), Luka konkurencyjna na poziomie przedsiębiorstwa a przystapienie Polski do Unii Europejskiej, Wydawnictwo Akademii Ekonomicznej w Poznaniu, Poznań 2002, s. 48-49.

${ }^{9}$ M.J. Stankiewicz, Istota i sposoby oceny konkurencyjności przedsiębiorstwa, „Gospodarka Narodowa", nr 7-8/2000, s. 79. 
jemnie zależnych elementów, które występują w tym samym horyzoncie czasowym i nawzajem się przenikają. Takie podejście podkreśla istnienie efektu ich synergicznego oddziaływania na konkurencyjność przedsiębiorstwa ${ }^{10}$.

Tabela 1. Uwarunkowania konkurencyjności przedsiębiorstw

\begin{tabular}{|c|c|c|c|c|}
\hline \multicolumn{5}{|c|}{ ZEWNĘTRZNE DETERMINANTY KONKURENCYJNOŚCI PRZEDSIĘBIORSTWA } \\
\hline & hniczne & Norn & ekologiczne & Normy prawne \\
\hline \multicolumn{5}{|c|}{ Wewnętrzne determinanty konkurencyjności przedsiębiorstwa } \\
\hline $\begin{array}{l}\text { Charakter } \\
\text { własności }\end{array}$ & $\begin{array}{c}\text { Organizacja } \\
\text { i zarządzanie }\end{array}$ & Public relations & $\begin{array}{l}\text { Kwalifikacje } \\
\text { pracowników }\end{array}$ & $\begin{array}{c}\text { Wielkość } \\
\text { i koszty produkcji }\end{array}$ \\
\hline
\end{tabular}

Źródło: opracowanie własne na podstawie: H. G. Adamkiewicz-Drwiłło, Konkurencyjność przedsiębiorstw..., op. cit., s. 248 i 306.

Czynniki mające źródło w otoczeniu przedsiębiorstwa są od niego niezależne. W znacznej mierze stanowią pochodną polityki władz państwowych i mechanizmów regulacji rynku, a także pozostają pod wpływem sytuacji gospodarczej w danym kraju, jak i koniunktury światowej. Z kolei czynniki wewnętrzne mają związek $\mathrm{z}$ działaniami podejmowanymi przez przedsiębiorstwo, są powiązane $z$ sytuacją finansową, posiadanymi zasobami materialnymi, kapitałem intelektualnym, strukturą organizacyjną, przyjętą strategią rozwoju, metodami zarządzania, przedsiębiorczością itp. Grupa czynników wewnętrznych jest utożsamiana $\mathrm{z}$ posiadanymi przez przedsiębiorstwo strategicznymi zasobami oraz umiejętnością ich wykorzystywania w celu podejmowania skutecznych działań, będących odpowiedzią i reakcją na zmiany i przeobrażenia zachodzące w otoczeniu zewnętrznym ${ }^{11}$.

Uwarunkowania konkurencyjności mogą stanowić zarówno jego czynniki wzrostu, co oznacza pozytywny wpływ na konkurencyjność, jak i przeszkodę - powodując spadek poziomu konkurencyjności ${ }^{12}$.

Konkurencyjność przedsiębiorstwa jest pochodną zdolności wykorzystywania posiadanych zasobów w procesach zdobywania kapitału klientów i kreowania kapitału intelektualnego. Należy ją rozumieć jako wynik wielopłaszczyznowych uwarunkowań, zależności i podejmowanych przez przedsiębiorstwo działań ${ }^{13}$.

${ }^{10}$ W. Walczak, Niematerialne determinanty konkurencyjności wspótczesnych przedsiębiorstw, [w:] S. Lachiewicz, M. Matejun, (red.), Konkurencyjnośc jako determinanta rozwoju przedsiębiorstwa, Wydawnictwo Politechniki Łódzkiej, Łódź 2009, s. 112-115.

${ }_{11}$ W. Walczak, Analiza czynników..., op. cit.

${ }^{12}$ H. G. Adamkiewicz-Drwiłło, Konkurencyjnośc przedsiębiorstw..., op. cit., s. 245.

${ }^{13}$ W. Walczak, Analiza czynników..., op. cit. 


\section{GLOBALNE STRATEGIE KONKURENCJI A KONKURENCYJNOŚĆ PRZEDSIĘBIORSTW}

Globalizacja wymusza na wszystkich przedsiębiorstwach konieczność głębokiej zmiany, dotyczącej praktycznie każdego z obszarów działalności przedsiębiorstwa. Nie każde przedsiębiorstwo taką zmianę może skutecznie podjąć i ją zrealizować. Strategia globalna przedsiębiorstwa to koncepcja dostosowania się przedsiębiorstwa do warunków globalizacji1 ${ }^{14}$.

Najbardziej widocznym wymiarem procesu globalizacji jest konkurencja - rozumiana jako rywalizacja gospodarcza między przedsiębiorstwami w skali świata. Konkurencja jest faktem i zarazem najpoważniejszym i bezpośrednim wyzwaniem dla zarządzania przedsiębiorstwem, ponieważ znacznie zwiększyła się liczba konkurentów na rynkach lokalnych oraz konkurencja jest walką nader często nieczystą, dopuszczającą się wielu niedozwolonych praktyk ${ }^{15}$.

Globalizacja przedsiębiorstwa pociągnęła za sobą globalizację konkurencji, a to z kolei zrodziło konieczność opracowania nowych - globalnych strategii konkurencji. Nacisk na stosowanie strategii globalnej wynika z potrzeby integracji działalności gospodarczej w związku z powstaniem rynków uniwersalnych, konieczności obniżania kosztów wytwarzania i dystrybucji oraz konieczności koordynacji działań w celu skutecznego przeciwdziałania różnym rodzajom konkurencji rynkowej. Wśród wielu strategii globalnych wyróżnia się następujące metody ekspansji globalnej: eksport, licencjonowanie, franszyzę, wspólne przedsięwzięcie, filię lub oddział za granicą ${ }^{16}$.

Budowanie przedsiębiorstw globalnych przejawia się głównie ${ }^{17}$ :

- powoływaniem przez danego producenta własnych filii handlowych w rożnych miejscach świata;

- udzielaniem licencji, wspólną organizacją dystrybucji, dostępem do projektów badawczo-rozwojowych;

- rozszerzaniem projektów „pod klucz”, polegających na tym, że wykonawca danego obiektu nie tylko go buduje i wyposaża w technologię, ale również np. szkoli pracowników;

- budowaniem międzynarodowych porozumień franszyzowych, w których występuje wzajemny wpływ franszyzobiorcy i franszyzodawcy sprzyjający przystosowywaniu się danego przedsiębiorstwa do lokalnych warunków;

\footnotetext{
${ }^{14}$ http://globalizacja.genialne.info/globalizacja_przedsiebiorstw.html (18.02.2013).

15 Ibidem.

${ }^{16}$ H.G. Adamkiewicz-Drwiłło, Konkurencyjnośc przedsiębiorstw..., op. cit., s. 398-399.

17 Ibidem, s. 400-401.
} 
— uruchamianiem produkcji kontraktowej polegającej na tym, że przedsiębiorstwo z jednego kraju lokuje w przedsiębiorstwie zagranicznym zamówienie na produkty, które są następnie sprzedawane pod znakiem firmowym i w sieci handlowej zamawiającego;

- tworzeniem przedsiębiorstw będących przedsięwzięciami wspólnymi, które zajmują się wytwarzaniem produktu, wniesionego przez jednego z partnerów, albo elementów do tego produktu;

- tworzeniem filii produkcyjnych stanowiących wyłącznie własność przedsiębiorstwa macierzystego, które mogą powstawać w drodze nabycia (wykupu) w całości istniejącego już przedsiębiorstwa i zaadaptowania go do własnych celów albo poprzez budowę od podstaw nowych jednostek.

Niejednokrotnie wzrost konkurencyjności przedsiębiorstw utożsamiany jest tylko z potencjałem techniczno-technologicznym, ale jak się wydaje należy również przy tym zagadnieniu uwzględnić rozwój umiejętności, kompetencji i lojalności pracowników realizujących cele przedsiębiorstwa. Wśród elementów wpływających na konkurencyjność przedsiębiorstw wymienia się przede wszystkim wzrost jego produktywności realizowany zwiększeniem efektów przy danych nakładach, kreowanie tendencji rozwojowych oraz skuteczne rozwijanie rynku zbytu poprzez rozbudowę sieci relacji.

Budowanie i realizowanie efektywnych globalnych strategii rozwoju jest niezwykle trudne biorąc pod uwagę wyzwania czekające na przedsiębiorstwa, chociażby znaczne przyspieszenie postępu technicznego i technologicznego, skracanie cyklu życia współczesnych produktów, trudności z identyfikacją potencjalnych klientów i rynków.

Zmienia się świadomość przedsiębiorstw związana $\mathrm{z}$ podejmowaniem przez nie wyzwań konkurencyjnych nie tylko na rynku lokalnym, ale również na arenie międzynarodowej. Sprostanie globalnej konkurencji poprzez stosowanie globalnych strategii konkurencji staje się nieodzownym elementem współczesnej gospodarki.

Postępująca globalizacja stawia przed przedsiębiorstwem wyzwania, które dotyczą między innymi: umiędzynarodowienia zarządzania, a więc nabycia nowych umiejętności (dostosowania kulturowe) tworzenia przedsiębiorstwa przyszłości (sieciowego, wirtualnego), zmiany potrzeb społecznych, technik i technologii (decentralizowanie), motywowania do stałego uczenia się ${ }^{18}$.

${ }^{18}$ K. Kubik, Wspótczesne przedsiębiorstwa wobec wyzwań globalnej konkurencji, „Zeszyty Naukowe Uniwersytetu Przyrodniczo-Humanistycznego w Siedlcach”, Seria: Administracja i Zarządzanie, Nr 92/2012, s. 43. 


\section{ZAKOŃCZENIE}

Podstawowym zadaniem każdego przedsiębiorstwa jest osiąganie efektywności i konkurencyjności w skali globalnej, a poprzez to maksymalnej sumy korzyści $z$ operacji zintegrowanych w skali światowej. Przedsiębiorstwo, aby mogło sprostać wyzwaniom globalizacji powinno zwiększać swoją konkurencyjność (biorąc przy tym pod uwagę wiele czynników, zarówno zewnętrznych - występujących w otoczeniu, jak i wewnętrznych). Od przedsiębiorstw wymaga się, aby potrafiły diagnozować stan i planować swój rozwój, wykazując się przy tym umiejętnościami efektywnego kształtowania działań i procesów, umożliwiających uzyskanie i utrzymanie określonej pozycji konkurencyjnej. W realiach współczesnej globalnej gospodarki konkurencyjność staje się jednym $\mathrm{z}$ ważniejszych wyznaczników i zarazem perspektyw oceny funkcjonowania przedsiębiorstwa na rynku i tylko przedsiębiorstwo konkurencyjne jest w stanie w tej gospodarce efektywnie funkcjonować.

Przedsiębiorstwo, aby mogło sprostać globalizacji musi być przedsiębiorstwem globalnym zorientowanym na wyniki: ściśle współpracującym z klientami i działającym na zasadach partnerskich, wewnętrznie integrującym współpracowników, wiarygodnym we współpracy z zewnętrznymi partnerami, zatrudniającym kadrę przedsiębiorczą, świadomą odpowiedzialności społecznej swojej i jednostki, mającym wizję i wyobraźnię oraz wiedzę interdyscyplinarną. Efekty działalności przedsiębiorstwa zależeć będą od myślenia globalnego, doceniania różnorodności kulturowej, działania opartego na systemie wartości, które będą zgodne $z$ etyką biznesu i zasadami moralnymi ${ }^{19}$.

Mimo, iż nie ma gotowych rozwiązań bądź strategii, gwarantujących każdemu przedsiębiorstwu zdobycie trwałej przewagi konkurencyjnej to należy podejmować np. próby naśladowania rozwiązań stosowane przez inne jednostki. Takie działania wymuszają niejednokrotnie zweryfikowanie dotychczasowego modelu zarządzania, zmianę sposobu myślenia, przyjmowanych postaw i zachowań organizacyjnych. Do tego niezbędne jest posiadanie rozległej i aktualnej wiedzy o czynnikach i uwarunkowaniach mających istotny wpływ na konkurencyjność przedsiębiorstwa.

\section{BIBLIOGRAFIA}

Adamkiewicz-Drwiłło H.G., Konkurencyjność przedsiębiorstw w świetle uwarunkowań wspótczesnej gospodarki, Wydawnictwo Dom Organizatora, Torun 2010.

${ }^{19}$ Ibidem, s. 44. 
Gorczyńska A., Globalizacja jako czynniki wspótczesnego wymiaru funkcjonowania przedsiębiorstw, [w:] W. Caputa, D. Szwajca (red.), Potencjat konkurencyjny przedsiębiorstwa w warunkach globalizacji, CedeWu.pl, Warszawa 2010.

Gorynia M. (red.), Luka konkurencyjna na poziomie przedsiębiorstwa a przystapienie Polski do Unii Europejskiej, Wydawnictwo Akademii Ekonomicznej w Poznaniu, Poznań 2002.

http://globalizacja.genialne.info/globalizacja_przedsiebiorstw.html (18.02.2013).

Kubik K., Wspótczesne przedsiębiorstwa wobec wyzwań globalnej konkurencji, „Zeszyty Naukowe Uniwersytetu Przyrodniczo-Humanistycznego w Siedlcach", Seria: Administracja i Zarządzanie, $\mathrm{Nr}$ 92/2012.

Leśniewski M.A., Konkurencyjność przedsiębiorstw. Wybrane problemy, Dom Organizatora, Torun 2011.

Stankiewicz M.J., Istota i sposoby oceny konkurencyjności przedsiębiorstwa, „Gospodarka Narodowa", nr 7-8/2000.

Talar S., Zmiany natężenia, charakteru $i$ znaczenia konkurencji we wspótczesnej gospodarce światowej, [w:] T. Sporka, S. Talar (red.), Internacjonalizacja i konkurencyjność wspótczesnych podmiotów gospodarczych, Wydawnictwo Uniwersytetu Ekonomicznego w Katowicach, Katowice 2011.

Walczak W., Analiza czynników wptywajacych na konkurencyjność przedsiębiorstw, „E-mentor”, nr 5 (37)/2010, http://www.e-mentor.edu.pl/artykul/index/nu$\mathrm{mer} / 37 / \mathrm{id} / 784$ (18.02.2013).

Walczak W., Niematerialne determinanty konkurencyjności wspótczesnych przedsiębiorstw, [w:] S. Lachiewicz, M. Matejun, (red.), Konkurencyjność jako determinanta rozwoju przedsiębiorstwa, Wydawnictwo Politechniki Łódzkiej, Łódź 2009. 